\title{
DIE GODDELIKE WETSORDE EN DIE BEOEFENING VAN DIE WETENSKAP.
}

Op 30 Januarie 1952 tydens die sitting van die Sinode van die Geref. Kerk het prof. dr. J. D. du Toit in die stadsaal van Potchefstroom 'n rede uitgespreek oor "Transformasie soos deur Vuur". In hierdie pragrede by geleentheid van die plaaslike viering van die Van Riebeeck-fees het prof. Du Toit daarop gewys dat die allesoorheersende feit in verband met die landing van Van Riebeeck was dat hy die „Christelike Religie” of die "Gereformeerde Christelike Leer" (soos Van Riebeeck self dit in sy bekende gebed bestempel het) hier na Suid-Afrika oorgeplant het.

In verband met hierdie leer sê prof. Du Toit: „,(Dit) besit alleen waarde, omdat dit vierkantig gegrondves is op die geopenbaarde Woord van God". Verder: „Dit spreek dus vanself dat Van Riebeeck die Bybel, algemeen bekend as die Statebybel, aan boord van sy skip gehad het. Die pakket waarin dit opgeberg was, was die kosbaarste wat hier aan wal gebring is." 
'n Bietjie later sê prof. Du Toit aldus: „Maar nou is daar ander waardevolle sake wat genoem moet word i.v.m. die Nederlandse okkupasie van die Kaap. Van Riebeeck noem die „Gereformeerde Christelike Leer”. Nou wel, hierdie leer vind sy vertolking in die Drie Formuliere van Enigheid.

Dat hulle drie i.v.m. die Skrif genoem word, het nie die bedoeling dat hulle maar enigsins 'n gelykwaardige plek naas die Skrif waardig gekeur mag word nie. Soiets kom nie in my gedagte op nie.

Die openbaring in die Skrif is absoluut uniek. Niks is daarmee enigsins gelykwaardig nie.

Maar nou is. daar in die Heilige Skrif ontsaglike dieptes. Vandaar dat God in sy voorsienigheid kanale beskik het waardeur die geheimenisse na ons toe gelei word.

Hierdie drie kanale is die Geloofsbelydenis, die Heidelbergse Kategismus en die Leerreëls teen die Remonstrante.

'n Suiwer en kernagtiger stelling van die saak wat betref die gefundeerdheid van die "Christelike Gereformeerde Religie" in die Woord van God, vir uitdrukking daarvan in die drie Formuliere van Enigheid as die Belydenisskrifte van die Christelike Kerk, is moeilik denkbaar en sal ook nie maklik gevind kan word nie.

Dit is hierdie Statebybel wat Van Riebeeck as sy kosbaarste pakket aan wal gebring het, dit is hierdie Christelike Religie wat Van Riebeeck op SuidAfrika se bodem geplant het, dit is hierdie drie Formuliere van Enigheid waarin die Gereformeerde vaders hulle diepste en heiligste geloofsoortuiginge vasgelê het en wat Van Riebeeck ons land binnegedra het-dit is hierdie dinge wat die Afrikanervolk van sy eerste oorsprong af gekenmerk het en wat hierdie volk in al sy doen en late, in $a l$ sy lewensuitinge, ten volle beheers het:

Dit is hierdie sake wat gedurende die drie eeue van sy bestaan die lewensbron en kragbron van ons volk gevorm het. Dit het koers en rigting op alle lewensterreine aan ons volk gegee. Dit het die Afrikanervolk gemaak tot wat hy is.

Prof. Du Toit konstateer terloops dat ons Belydenisskrifte in onbekendheid en sodoende in onmin geraak het. Dit is nie ons taak om hier na te speur in watter opsigte presies die Bybel en die Belydenisskrifte die kragbron van ons volk was en nog is nie. Dit is ook nie ons taak om hier na te gaan in watter opsigte presies die Bybel en die Belydenisskrifte by ons volk alreeds in onbekendheid en gevolglik in onmin geraak het nie. 
Wat ons hier wel terdeë met die grootste nadruk wens te stel is dat in verband met die beoefening van die wetenskap in Suid-Afrika daar van die aanvang af tot hede ten dage nog weinig rekening gehou is met die fundamentele openbaringswaarhede van die Heilige Skrif. Op wetenskaplike gebied word daar weinig gemerk van die invloed van die Bybel en die Belydenisskrifte wat Jan van Riebeeck as goue kleinode na Suid-Afrika gebring het en wat deur sy geskiedenis heen die Afrikanervolk in sy gebondenheid aan God en sy heilige Gebod bewaar het.

Dat 'n magtige gevaar ons op wetenskaplike gebied bedreig, is gewis en seker. Byna daagliks verneem ons die bewering dat die Skrif en die fundamentele Christelike waarhede ' $n$ belemmering is vir die vooruitgang van die wetenskap. Immers, die sogenaamde openbaringsbeginsels is in stryd, hulle is onversoenbaar met die bevindinge van die wetenskap, met name van die Natuurwetenskap.

Met hierdie standpunt asook met die beweringe wat daaruit voortvloei, kan die P.U. vir C.H.O. hom nie versoen nie. Hierteenoor moet hy noodgedwonge die stryd aanbind.

In die hiervolgende uiteensetting aangaande Die Goddelike Wetsorde en die Beoefening van die Wetenskap trag ons in alle beskeidenheid ' $n$ aanduiding te bied van die fundamentele beginsels waarmee die P.U. vir C.H.O. rekening hou in sy wetenskaplike arbeid, fundamentele beginsels wat o.i. geen inbreuk maak op datgene wat Van Riebeeck as die kosbaarste besit aan ons Afrikanervolk oorgedra het.

Met sy spreuk In U Lig stel die P.U. vir C.H.O. hom op ondubbelsinnige wyse op die standpunt van Gods Woord, wat vir hom die Besondere Openbaring bevat.

Van die verskillende fundamentele beginsels van die Besondere Openbaring waarmee in die beoefening van die Wetenskap rekening gehou moet word, beperk ons ons tot die volgende, en ons stel dit so saaklik moontlik.

\section{Die verhouding tussen God en die wêreld (kosmos) moet altyd suiwer gestel word.}

God is die Skepper en die kosmos die geskapene.

Tussen God as Skepper en die kosmos as die geskapene moet duidelik onderskei word, en een fundamentele onderskeiding tussen beide is die Wet. Die Wet is 'n grens wat die mens nie kan oorskry nie maar ook nie kan vernietig nie. 


\section{God as Skepper is verhewe bo die Wet.}

God is Wetgewer. Hy gee die wette, Hy stel die wette daar wat die kosmos beheers. As Wetgewer staan God noodwendig bo die Wet. As God nie bo die Wet staan nie, moet Hy na sy wese gelykgeskakel word met die kosmos; dan vloei Hy na sy wese met die kosmos saam. Dit is 'n onmoontlikheid.

\section{Die skepping of kosmos staan onder die Wet.}

Die Wet beheers die kosmos. Alleen maar: Wet moet nie beskou word uitsluitlik in die sin van die Sedewet of van die Tien Gebooie nie. Nee, dit omvat veel meer; daar is ' $n$ oneindige menigvuldigheid van wette. Die term Wet sluit in al die wetmatighede, al die ordinansies van God wat die kosmos, die heelal, in sy geestelike sowel as in sy natuurlike (stoflike) order beheers.

\section{Daar is in die heelal verskillende soorte wette.}

In die verbysterende menigvuldigheid van wette of ordinansies wat die skepping van God in sy verskillende dele beheers, kan daar 'n bepaalde aantal soorte wette onderskei word. So word deur die Calvinistiese Wysbegeerte in Nederland (die Wysbegeerte van die Wetsidee) gewoonlik veertien soorte verskillende wette onderskei. Hulle is in die volgorde van laere na hoëre: die aritmetiese, ruimtelike, fisiese, biotiese, psigiese, analitiese (logiese), historiese, linguistiese (taalkundige), sosiale, ekonomiese, estetiese (kuns-), juridiese (regs-), etiese (sedelike) en pistiese (religieuse geloofs-) wette.

Hierdie verskillende soorte wette bind wat onder hulle val, in wetskringe saam.

5. Die verskillende wetskringe in hulle verhouding tot mekaar vorm die kosmiese orde.

Die wette van die verskillende kringe kan en mag nie tot mekaar herlei word nie. As poginge aangewend word om hulle wel tot mekaar te herlei of hulle met mekaar te vereenselwig, dan ontstaan daar logiese teenstrydighede en word die wêreldbeeld wat die wetenskap trag te ontwerp, verwronge en vals. 
Hoewel die wette van die verskillende kringe nooit tot mekaar herlei mag word nie, staan die wette tog desnietemin met mekaar in 'n bepaalde eenheidsverhouding. Eerstens volg die kringe op mekaar; die hoëre is op die laere gebou of in die laere gefundeer. Tweedens gryp die wette van die laere kringe vooruit op (antisipeer hulle) die van die hoëre en gryp die wette van elke hoëre kring terug (retrosipeer hulle) op die van die laere.

Tesame vorm die sisteem van die wetskringe wat genoem word die kosmiese wetsorde.

6. Die wette van die verskillende kringe beheers gevolglik die individuele dinge en wesens in die kosmos wat betref hul bestaan en werking.

'n Fisiese ding (sê 'n klip) word byvoorbeeld beheers deur die wette van die aritmetiese, ruimtelike en fisiese kringe; 'n plant deur die wette van die genoemde drie kringe plus die wette van die biotiese kring; 'n dier deur die wette van die vier laagste kringe plus die wette van die psigiese kring, terwyl die mens as kroonstuk van God se skepping beheers word deur die wette van al die kringe, d.w.s. deur die wette van die aritmetiese tot en met die pistiese kring.

Die eerste vyf soorte wette kan nie oortree word nie en sou natuurwette genoem kan word. Die laaste nege soorte wette is wette wat oortree kan word en word norme genoem. Menslike vryheid is moontlik omdat die mens in die nege hoogste wetsoorte onder 'n normatiewe orde staan.

\section{7. 'n Ware kennis van God kan alleen verkry word uit sy Woord, uit sy Besondere Openbaring.}

God openbaar Hom wel deur sy skepping (art. II van die Nederlandse Geloofsbelydenis), maar 'n suiwere, duidelike en menslik volkome kennis van God, sy Wese, van sy raadsplan en van sy wil sou vir die mens onmoontlik gebly het, was dit nie dat God Homself ook geopenbaar het in sy Besondere Openbaring, wat die inhoud van sy Heilige Woord vorm nie. Hierdie inhoud is aan die mens gegee in vorme en begrippe wat tot die kosmos self behoort, wat deel uitmaak van die kosmos. Vandaar dat datgene wat God van Homself geopenbaar het, deur die mens verstaan en begryp kan word. Deur die mens word geglo dat dit inderdaad die Waarheid is.

\section{Kennis van die mens is en bly beperk tot dinge en wesens van die kosmos.}

Bo die grens wat die kosmos (en dus ook die mens) van God onderskei, kan die mens met sy kennis nie uitstyg nie. Hy kan God nie ken soos God 
Homself ken nie. Ook die skerpste intellek bly in sy wetenskaplike beoefening beperk slegs tot die gegewens van die veertien wetskringe wat die ondersoekingsterrein van die basiese wetenskappe vorm.

9. Hoewel die Besondere Openbaring in die eerste en belangrikste plek kennis aangaande God self bevat, bied dit ook kennis aangaande die oorsprong, wese en bestemming van die kosmos, veral van die mens.

Onder meer leer Gods Woord as besondere openbaring ons dat hoewel die mens die Wet as grens tussen God en die skepping nooit kan oorskry nie, dit geen beperking is ten opsigte van God self nie. Immers, nie alleen is God Skepper nie, maar na sy almag en sy alomteenwoordigheid dra, onderhou en regeer Hy die ganse skepping met alles wat hulle daarin bevind, tot vandag toe en vir altyd.

Wat God van Homself en van die oorsprong, wese en bestemming van die kosmos en veral van die mens openbaar, belig vir ons die kosmos, laat ons die kosmos in die juiste verhouding tot God sien, en met hierdie lig moet die beoefenaar van die wetenskap rekening hou. Hy sal die kosmiese wetsorde wat hy trag te ontdek en te formuleer, sien as 'n wetsorde van God volgens die openbaring in sy Heilige Woord.

In alle beskeidenheid durf ons beweer dat bostaande van die mees fundamentele beginsels aandui waarmee in die onderwys en die beoefening van die wetenskap aan die P.U. vir C.H.O. rekening gehou word. Hierteenoor vorm die wetenskap wat nie met die beginsels van die Besondere Openbaring van God geen rekening hou nie, 'n drastiese en onversoenbare teëstelling. Die wetsorde wat hierdie wetenskap soek en formuleer, is ' $n$ gans andere as die Skriftuurlik beligte.

Veral in drieërlei opsig word daar deur die laasgenoemde wetenskap gedwaal:

a. Ten opsigte van die verhouding tussen God en kosmos.

Die Wet as grens tussen beide word nie gehandhaaf of nie suiwer gehandhaaf nie. Dan word óf die bestaan van God ontken (ateïsme), óf God word met die wêreld vereenselwig (panteïsme), ó die bestaan van die wêreld word ontken (akosmisme), of die wêreld word in God opgelos (panteïsme), of die wêreld word gedeeltelik met God vereenselwig (parsiële kosmisme), en so is daar nog enkele ander moontlikhede.

Geeneen van hierdie standpunte kan ons aanvaar nie; hulle word deur die Calvinisme heftig bestry. Hulle gee almal 'n verwronge en valse beeld 
van die kosmos en van die kosmiese wetsorde en lei die wetenskap op dwaalspore. Ons leer die teĩsme, wat die Wet as grens tussen God en die wêreld en as 'n van God gegewe wet vir die kosmos onverbiddelik handhaaf.

\section{b. Ten opsigte van die onherleibaarheid van die wetskringe in die kosmiese wetsorde.}

Een of ander van die wetskringe word as primêr gestel ,en die ander word dan daaraan ondergeskik gestel. Met ander woorde die outonomie van slegs een of ander soort wet word as absoluut gehandhaaf, en al die ander soorte wette word tot hierdie een soort herlei. Om enkele voorbeelde te noem: word die fisiese of meganiese wet as absoluut gestel, dan het ons fisisisme of materialisme of meganisme; word die biotiese wet as sodanig gestel, dan het ons biologisme of vitalisme of evolusionisme of holisme. So kan ons kry psigologisme of rasionalisme, al na gelang die psigiese of die logiese wet as primêr of absoluut beskou word.

Al dergelike gevalle is onversoenbaar met die Skriftuurlike skeppingsleer of kreasianisme, wat handhaaf dat God 'n verskeidenheid van wesens geskape en 'n verskeidenheid van wette in sy skepping gelê het.

c. Ten opsigte van die samehang van die wetskringe, d.w.s. van die eenheid van die kosmiese wetsorde.

Twee of meer van die wetskringe word onderskei, maar die verband tussen hulle word geloën. Dan ontstaan 'n dualisme of 'n pluralisme in die wetenskap. So word byvoorbeeld gees en stof of natuur en kultuur of godsdiens en wetenskap uitmekaar geskeur. Daarmee word die eenheid van die waarheid en die eenheid van die kosmiese wetsorde vernietig. Ook dit bestry die Calvinisme heftig.

Die wetenskap wat met Gods Woord geen rekening hou nie en wat 'n wetsorde huldig wat daarmee in stryd is, vertoon 'n beeld van wanorde, van skole en rigtinge wat mekaar in fundamentele sake bestry.

Daarteenoor is vir die P.U. vir C.H.O. die diepste grond van die wetenskap God uit Wie, deur Wie en tot Wie alle dinge is en beoefen hierdie inrigting die wetenskap Soli Deo Gloria.

J. C. VAN ROOY. 